\title{
Building Climate Change Adaptation Scenarios with Stakeholders for Water Management: A Hybrid Approach Adapted to the South Indian Water Crisis
}

\author{
Mariem Baccar ${ }^{1, *}$, Jacques-Eric Bergez ${ }^{1}$, Stephane Couture ${ }^{2}$, Muddu Sekhar ${ }^{3} \mathbb{D}$, Laurent Ruiz ${ }^{3,4,5}$ \\ and Delphine Leenhardt ${ }^{1}$ \\ 1 AGIR, INRAE, Université de Toulouse, F-31326 Castanet-Tolosan, France; \\ jacques-eric.bergez@inrae.fr (J.-E.B.); delphine.burger-leenhardt@inrae.fr (D.L.) \\ 2 MIAT, INRAE, F-31326 Castanet-Tolosan, France; stephane.couture@inrae.fr \\ 3 Indo-French Cell for Water Sciences, Indian Institute of Science, Bangalore 560012, India; \\ muddu@iisc.ac.in (M.S.); laurent.ruiz@inrae.fr (L.R.) \\ 4 SAS, INRAE, Institut Agro, F-35000 Rennes, France \\ 5 GET, CNRS, IRD, UPS, F-31400 Toulouse, France \\ * Correspondence: mariem.baccar@inrae.fr
}

check for

updates

Citation: Baccar, M.; Bergez, J.-E.; Couture, S.; Sekhar, M.; Ruiz, L.; Leenhardt, D. Building Climate Change Adaptation Scenarios with Stakeholders for Water Management: A Hybrid Approach Adapted to the South Indian Water Crisis. Sustainability 2021, 13, 8459. https:// doi.org/10.3390/su13158459

Academic Editors: Giovanni De Feo and César Martín-Gómez

Received: 9 June 2021

Accepted: 26 July 2021

Published: 28 July 2021

Publisher's Note: MDPI stays neutral with regard to jurisdictional claims in published maps and institutional affiliations.

Copyright: (c) 2021 by the authors. Licensee MDPI, Basel, Switzerland. This article is an open access article distributed under the terms and conditions of the Creative Commons Attribution (CC BY) license (https:// creativecommons.org/licenses/by/ $4.0 /)$.

\begin{abstract}
Climate change threatens the sustainability of agriculture and natural resources. Adaptive solutions must be designed locally with stakeholders. We developed the Approach for Building Adaptation Scenarios with Stakeholders (ABASS), which aims to identify adaptation policies and corresponding scenarios of natural resource management in the context of climate change. Its originality is the combination of different existing participatory methods, organized in three phases. In step 1, experts identify local environmental problems on a map and build the assumption tree of local climate change effects. In step 2, experts identify stakeholders. Step 3 leads to the construction of adaptation scenarios with stakeholders in two phases. First, in a participatory workshop gathering numerous stakeholders, the assumption tree is presented to help stakeholders identify potential policies that address the effects of climate change. Then, using the map produced in step 1, each group of stakeholders separately translates each potential policy into a detailed scenario. We applied ABASS to the context of groundwater overexploitation in South India. Two policies at the farm level emerged as consensual: (i) ponds to harvest runoff water and (ii) drip irrigation to conserve water; but their implementation highlights the differences of opinion among stakeholders.
\end{abstract}

Keywords: participatory approach; farming system sustainability; natural resource management; management policy; groundwater overexploitation; tropics

\section{Introduction}

Climate change is expected to intensify water scarcity in regions where irrigation sustains agriculture, as is the case in India [1]. At the same time, an increasing population means that irrigation is necessary to increase food production. Both influence the need for adaptation strategies and for methodological approaches to identify and evaluate these strategies [2].

Approaches such as scenario development, modelling and evaluation are classic ways to explore adaptation strategies in the water resource domain and to address climate change effects [3]. They are associated with participatory approaches, and in recent decades several participatory stakeholder frameworks have been designed and implemented in projects that address adaptation strategies for groundwater management [4]. Decision-making processes related to natural resource management are receiving increasing attention from local to international levels [5]. Stakeholders' involvement and participation are recognized as a key aspect of sustainable management of groundwater, as they provide reliable information and inputs, which make research more robust [6,7]. For adaptation strategies 
to be effective and accepted at the local level, Barreteau et al. [8] recommend considering the perspectives on local interests and priorities of multiple stakeholders.

According to the literature, stakeholders are defined as entities (individuals, groups or organisations) that affect or can be affected by a decision $[9,10]$. The degree of stakeholder integration in participatory approaches depends on the objective of the approach (communicate, consult or participate) [8]. Participation is a process in which stakeholders have a role in making decisions that affect them [11,12]. Classic frameworks of the participatory approach are organized around three steps: (i) identify the environmental problem to be addressed and define its social and natural boundaries, (ii) identify the stakeholders affected by or who can affect the natural system considered and (iii) select the most relevant stakeholders for the specific objectives of the project and engage them in project activities $[13,14]$. Such approaches were used for example for identifying sustainable farming practices $[15,16]$, designing natural resource management and conservation schemes $[17,18]$ or assessing livelihood strategies $[19,20]$ in different regions of the world.

In this article, we (i) describe a new participatory approach for building adaptation scenarios with stakeholders to explore water resource management strategies that address climate change and then (ii) apply the approach to a case study. The approach, based on the classic framework of the participatory approach, is adapted to the context of the Indian "water crisis" [21]. The originality of our approach is the combination of different methods to structure the groundwater issue and to engage stakeholders in identifying solutions adapted to the region, which has a diversity of biophysical and socio-economic situations. As in the "story and simulation" [22,23] and "participatory model building" [24] approaches, our approach encourages strong involvement of stakeholders in the scenariobuilding process, with a high level of interaction focused on potential solutions and adaptation scenarios.

\section{Materials and Methods}

\subsection{Study Area}

The Berambadi watershed $\left(11^{\circ} 43^{\prime} 00^{\prime \prime}\right.$ to $11^{\circ} 48^{\prime} 00^{\prime \prime} \mathrm{N}, 76^{\circ} 31^{\prime} 00^{\prime \prime}$ to $\left.76^{\circ} 40^{\prime} 00^{\prime \prime} \mathrm{E}\right)$ is located in southwest India and covers an area of $84 \mathrm{~km}^{2}$ (Figure 1). This watershed is mainly composed of an agricultural area that extends over 15 villages in the east and centre and a forest area that predominates in the west and belongs to the Bandipur National Park. In the Berambadi, groundwater resources are intensively monitored since 2009, under the Kabini Critical Zone Observatory (SNO M-TROPICS, part of OZCAR research infrastructure) [25]. These long-term observations show large spatial variations in depletion and quality due to groundwater overexploitation, mainly for irrigation [26,27]. Indeed, water availability is an important factor that influences farm diversity in this watershed [28]. Farmers try to adapt to this situation, either by increasing the number of borewells or by changing their irrigation practices and cropping patterns according to groundwater availability [29]. However, groundwater depletion is likely to worsen because of climate change, and exacerbation of groundwater overexploitation has become a real concern [30]. Thus, exploring effective and specific adaptation policies to manage the water crisis in this context becomes necessary.

\subsection{ABASS Development and Steps}

Our Approach for Building Adaptation Scenarios with Stakeholders (ABASS) consists of three steps (Figure 2). The first two steps involve local scientific experts in multiple fields (e.g., sociologists, hydrologists, agronomists) and understanding an extensive body of information, including biophysical and socio-economic data. The third step involves local stakeholders, mainly policymakers, or those who influence public development policies. 


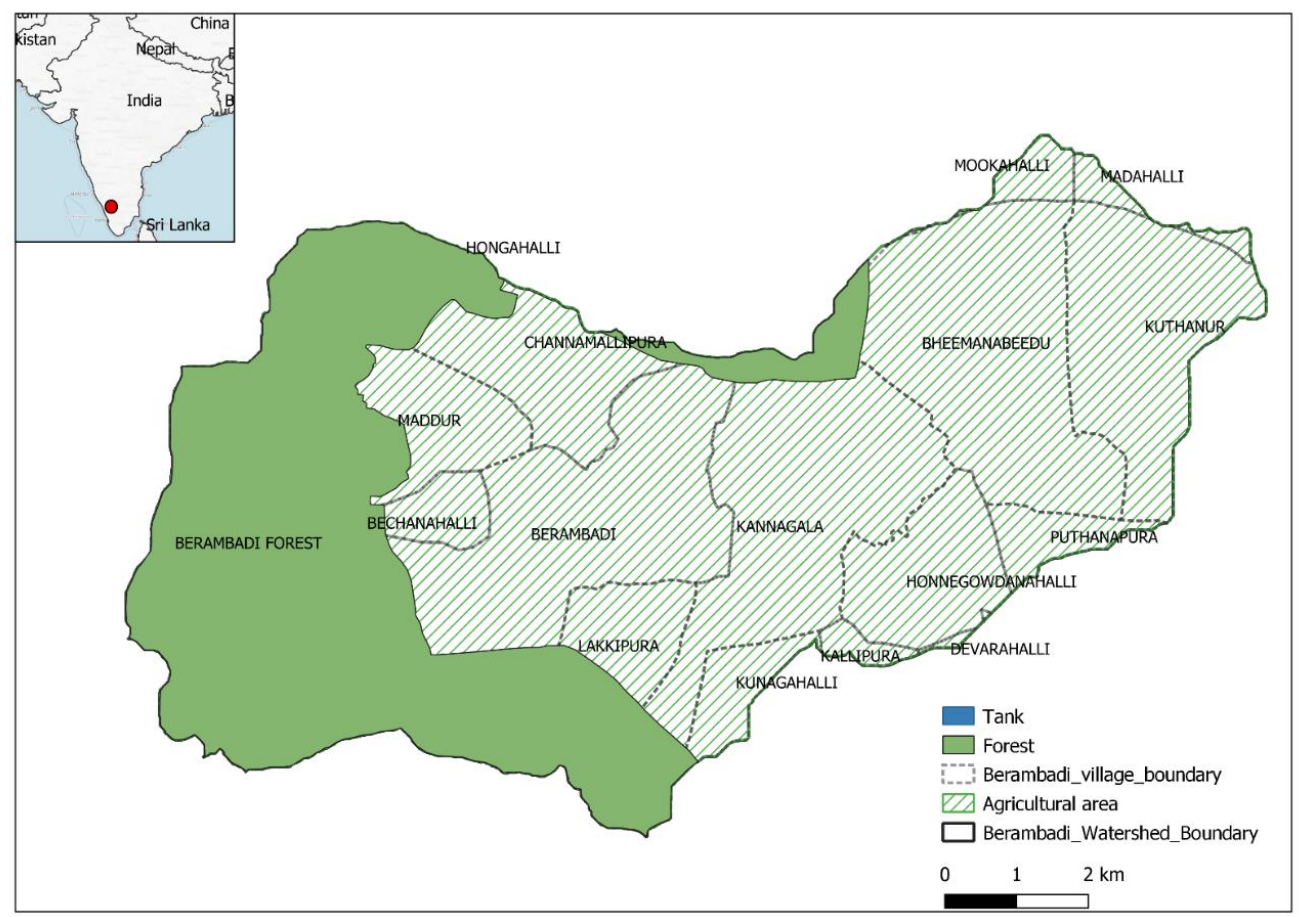

Figure 1. Berambadi watershed location.

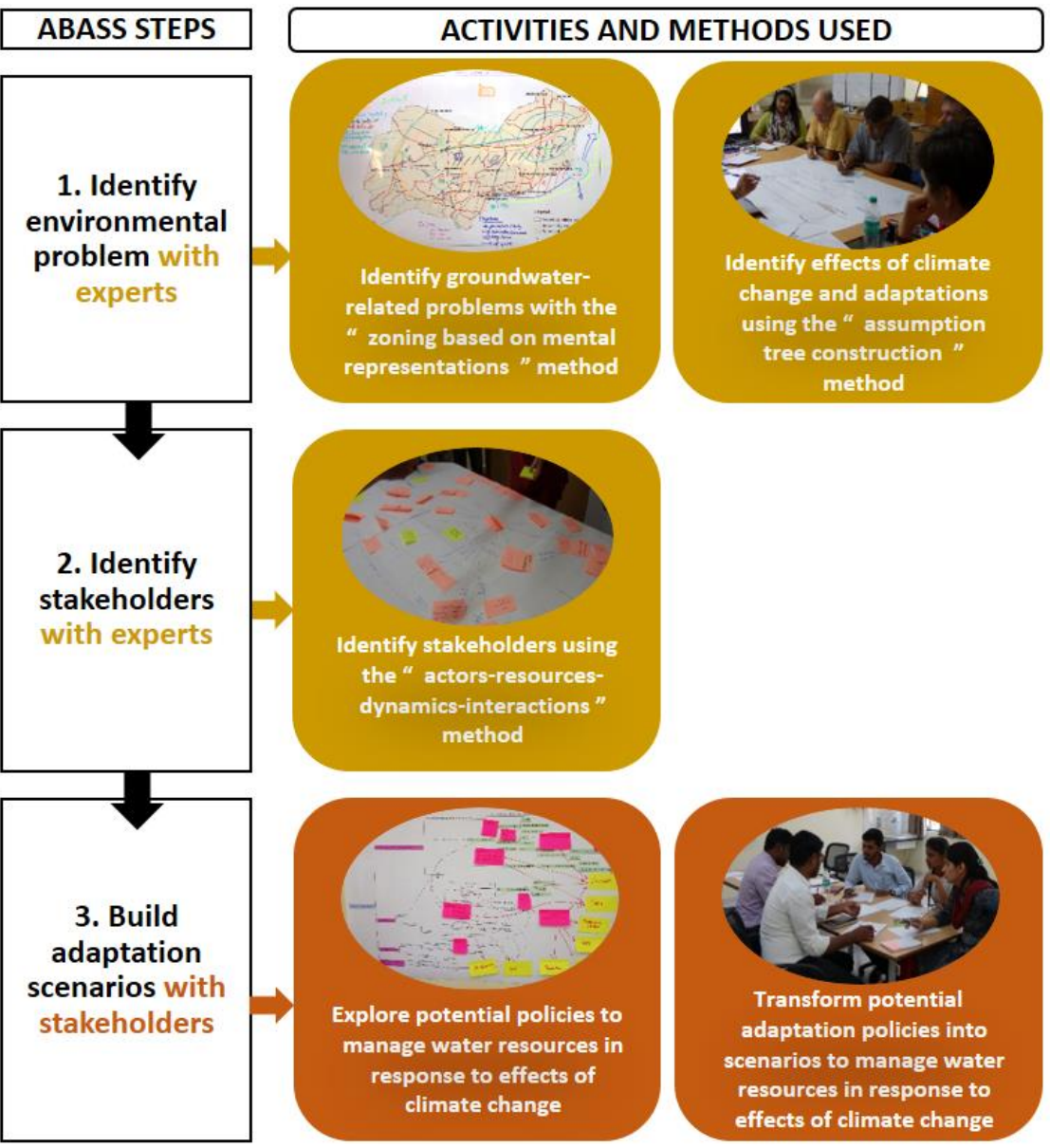

Figure 2. Main steps of the ABASS approach for building adaptation scenarios with stakeholders. 


\subsubsection{Step 1: Using Expert Knowledge to Identify the Environmental Problem}

This first step aims to provide clear understanding of the functioning of the ecological and socio-economic system that could be affected by the adaptation scenarios $[9,23]$. Scientific studies help in understanding the problem of local groundwater overexploitation, potential effects of climate change on groundwater use and overexploitation, as well as the effects that these problems may have on other components of the territory [31]. To provide a complete overview of the biophysical and socio-economic functioning of the Berambadi watershed and to understand the main issues for groundwater management due to effects of climate change, we used two participatory methods to obtain scientific knowledge: "zoning based on mental representations" (ZADA) and "assumption tree construction" (ATC).

- Identifying groundwater-related problems using the ZADA method

To represent fully the ecological and socio-economic system related to the groundwater problem, we used the ZADA method [32] with the scientific experts. In ZADA, individuals share information in a spatial manner by drawing and describing areas or sectors on a map that have resource management problems [33,34].

- Identifying climate change effects and adaptation mechanisms using the ATC method

To understand effects of climate change in the Berambadi watershed, we used the ATC method, which has three phases: (1) brainstorming about (i) the climate change that has occurred or is likely to occur, (ii) the effects (direct or indirect) on groundwater resources and local agriculture and (iii) the current adaptation strategies farmers use to address these changes; (2) organising the elements that the experts identified into causal chains that connect climate change, its impacts on the watershed and the potential adaptations adopted by farmers and (3) organising these causal chains in an assumption tree with connections between branches (because a change can have several effects, and one effect can lead to several adaptations).

2.2.2. Step 2: Using the "Actors-Resources-Dynamics-Interactions" Method with Experts to Identify Stakeholders

Researchers' knowledge of the functioning of an ecological system is a relevant way to characterise and select its stakeholders $[13,35]$. Therefore, we used as experts several scientists who work in the Berambadi watershed to identify stakeholders associated with groundwater management. We adapted the "actors-resources-dynamics-interactions" (ARDI) method [36], which was already used in several case studies to map interactions between stakeholders and resources (and their dynamics) in a particular area [37,38]. We asked participants to (i) identify direct stakeholders involved in using and managing groundwater resources and their management entities and indirect stakeholders whose actions could influence management strategies of the direct stakeholders; (ii) determine resources related to groundwater resource management and (iii) identify interactions among the stakeholders and between stakeholders and resources. This participatory method identified the socio-political system associated with groundwater management, as well as multiple stakeholders who can affect or are affected by the groundwater system at different levels of integration (from local to national levels).

\subsubsection{Step 3: Building Adaptation Scenarios with Stakeholders}

This step involves developing qualitative storylines, which the research team subsequently quantifies and simulates using a model. To develop storylines on water resource management policies in the context of climate change, we selected stakeholders involved in policymaking at different levels [39]. These stakeholders, selected from those identified by the ARDI method, were engaged in the two phases of the adaptation-scenario-building process: (i) explore potential policies to manage water resources and address effects of climate change and (ii) transform these policies into scenarios that can be simulated. 
- Exploring potential policies to manage water resources in response to effects of climate change

We selected stakeholders from governmental and technical institutions involved in policymaking related to water resource management in the region. We invited these stakeholders to participate in a workshop to identify potential policies that address effects of climate change. We used the assumption tree built by the experts as food for thought. We asked each participant to select one (or more) climate change effect(s), develop an adaptation strategy for addressing the selected effect(s) and explain how to translate it into a policy by specifying its purpose, its targeted scale and how to implement it. Each policy was placed on the tree and discussed with all participants. Afterward, we classified the policies by their purpose and targeted scale.

- Transforming potential adaptation policies into scenarios to manage water resources in response to the effects of climate change

Moving from a narrative description of a potential policy to a scenario that can be simulated using models requires translating the information into numerical model inputs [40]. We translated the two most common and thus representative policies. To capture most of the differences in opinion about how to implement policies, we selected stakeholders from different domains (institutional, technical and civil society) who are essential to policymaking. The translation step was performed independently with each group of stakeholders. We used the map built during the ZADA step as an intermediate object $[41,42]$ to help stakeholders contextualise and spatialise the policy.

\section{Results: Applying ABASS to the Groundwater Crisis in South India}

\subsection{Environmental Problem According to Expert Knowledge}

The scientific experts involved were specialized in a variety of scientific fields and affiliated with several scientific institutions (Indian Institute of Science, Indo-French Cell for Water Sciences, and the French Institute of Pondicherry) and a non-governmental development organisation (NGO). These scientific experts, all involved in research and development activities in the Berambadi watershed, helped us identify biophysical and socio-economic problems inherent in the exploitation of groundwater, as well as the stakeholders involved in using and managing the groundwater.

\subsubsection{Berambadi, an Area Dominated by a Gradient of Rainfall and Groundwater Level}

The map produced by ZADA summarises the biophysical mechanisms and social dynamics in the Berambadi watershed (Figure 3). The watershed has a significant east-west gradient of rainfall and groundwater levels, which are connected by the recharge process. In the eastern zone of the watershed, development of irrigation since the 1990s resulted in a rapid decrease in groundwater levels and pump yields. In the western zone, rainfall and groundwater levels are higher. This gradient influences the spatial distribution of farming systems in the area strongly. In the east, farmers have mixed cropping systems (mainly vegetables and turmeric) and are adapting quickly to groundwater depletion by increasing the number of borewells or changing their irrigation practices or cropping systems. In the west, where irrigation developed later, farmers have a wider variety of cropping systems with irrigated crops (e.g., turmeric, sugar cane, banana, vegetables) and rainfed crops. Marigold cropping (rainfed) is widespread in this zone due to contract farming with a local industry. In addition to water availability, soil types affect the crop choice. Black soils (fertile, deep, good water holding capacity, located mostly in valleys) are more suitable for irrigated cash crops (perennial crops, horticulture) than red soils (poor, low water holding capacity). Historically, many water tanks were used for irrigation, but they are no longer filling, due to the disappearance of incoming base flow related to the decrease in groundwater level and to climate change. They are now used only as a source of sediments to apply to soils of farms in the region. Moreover, spatial disparity in socio-economic development has resulted in different migratory movements: long-term and seasonal migrations of landless workers from the east of the watershed to other states 
or neighbouring cities, and daily migrations from the east to the west of the watershed, both of which are facilitated by bus lines.

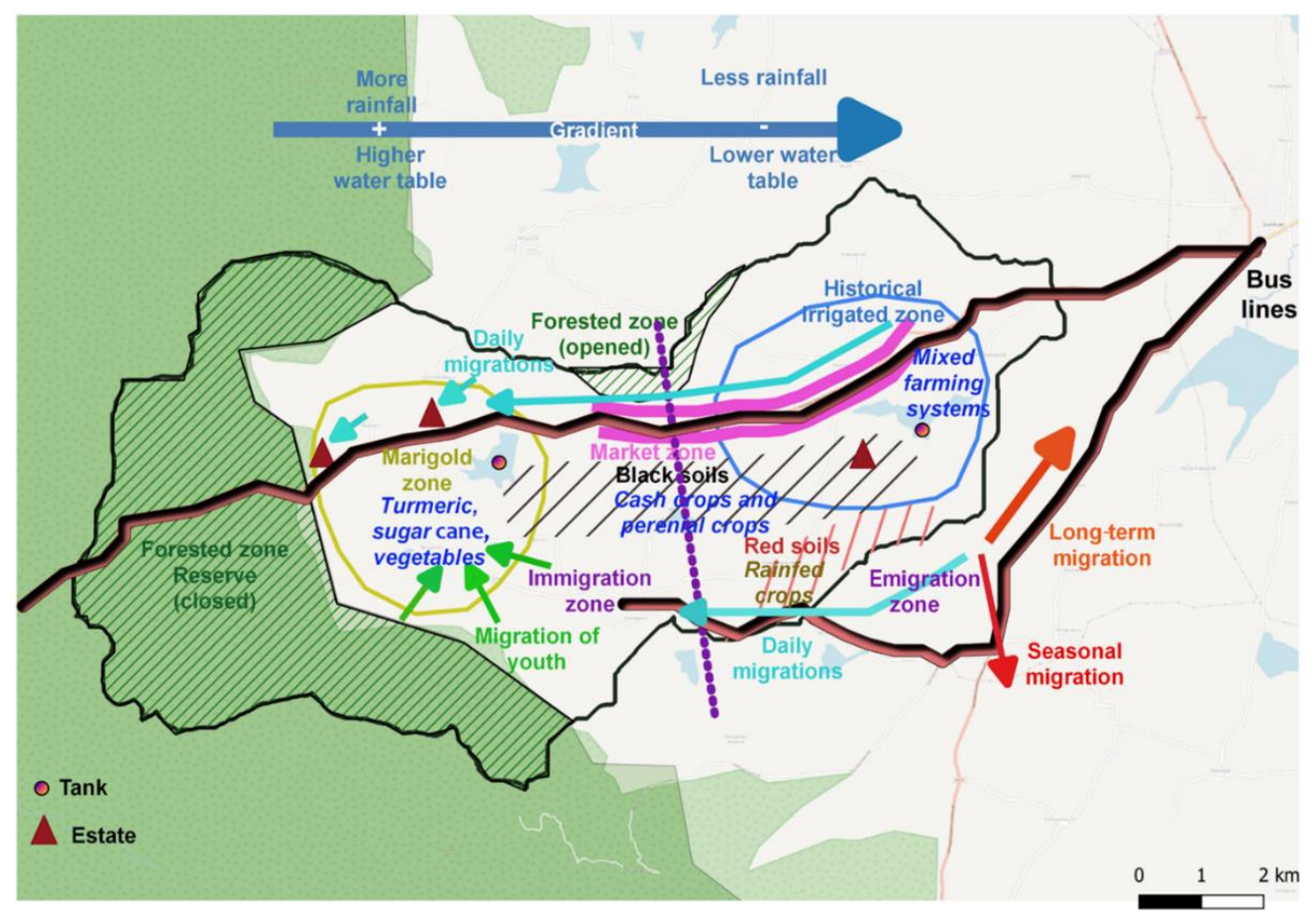

Figure 3. Map developed from participatory zoning of water-related issues using the "zoning based on mental representations" method.

\subsubsection{A Wide Diversity of Climate Change Effects and Adaptations in Berambadi}

According to the experts, the main effects of climate change in the Berambadi watershed are (i) an increase in temperature, (ii) a decrease in the number of rainy days but no change in annual rainfall amount, (iii) a delay in the start of the monsoon and (iv) an increase in the frequency of extreme events (Figure 4). Through causal chains, these effects have negative consequences on water and soil resources, agricultural production, crop yields, farm and regional socio-economic development and wildlife. Moreover, several causal chains of different climate change effects are interconnected. Experts identified three types of farmer adaptations: technical adaptations that address the decrease in groundwater levels, agronomic adaptations that address the decrease in crop yields and socio-economic adaptations that address the decrease in income.

\subsection{An Intricate Network of Stakeholders Identified by Experts}

Four major groups of stakeholders that affected or were affected directly or indirectly by these problems were identified (Figure 5): farmers, villages, government institutions, and businesses. Among farmers, irrigating farmers affect groundwater directly by pumping it for irrigation. However, their use of groundwater depends on the availability of energy for pumping and on the choice of cropping system, which in turn is influenced by business (e.g., market, contract farming) and decisions made at the village scale (e.g., programmes and subsidies, labour availability, NGO programmes). Panchayats (village authorities) affect groundwater directly by pumping it to supply drinking water to villages. Among government institutions, the watershed development department (WDD) operates at the state scale and is the only stakeholder that influences groundwater directly, through programmes for groundwater recharge via surface water and for surface water conservation. The WDD is directly connected to the local agricultural technical and advisory centre (KVK) to design and disseminate development programmes at the district scale. The 
energy supplier affects groundwater indirectly via decisions about the amount of time that electricity is distributed to farmers for pumping.

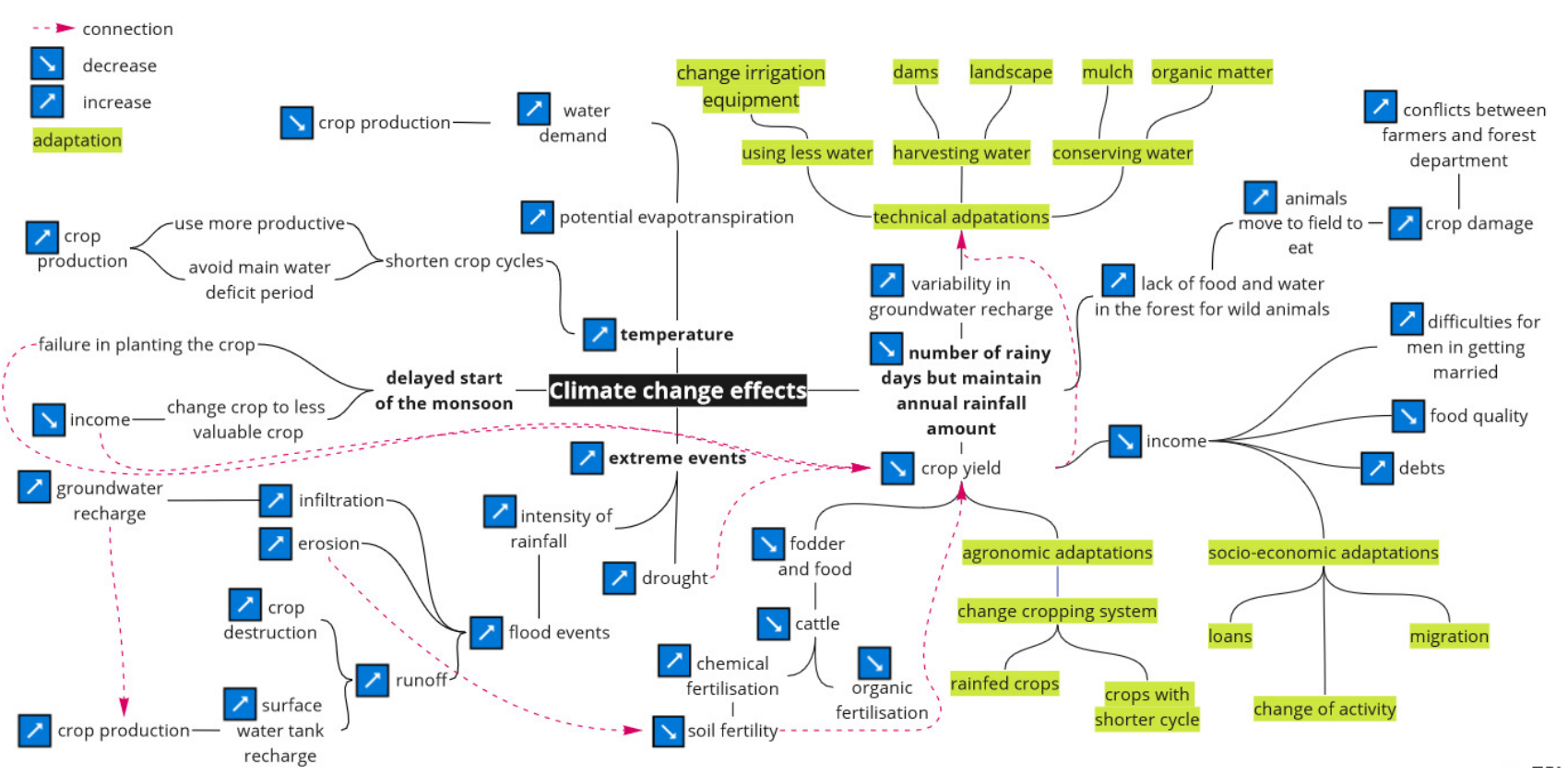

Figure 4. Assumption tree for climate change effects developed using the "assumption tree construction" method.

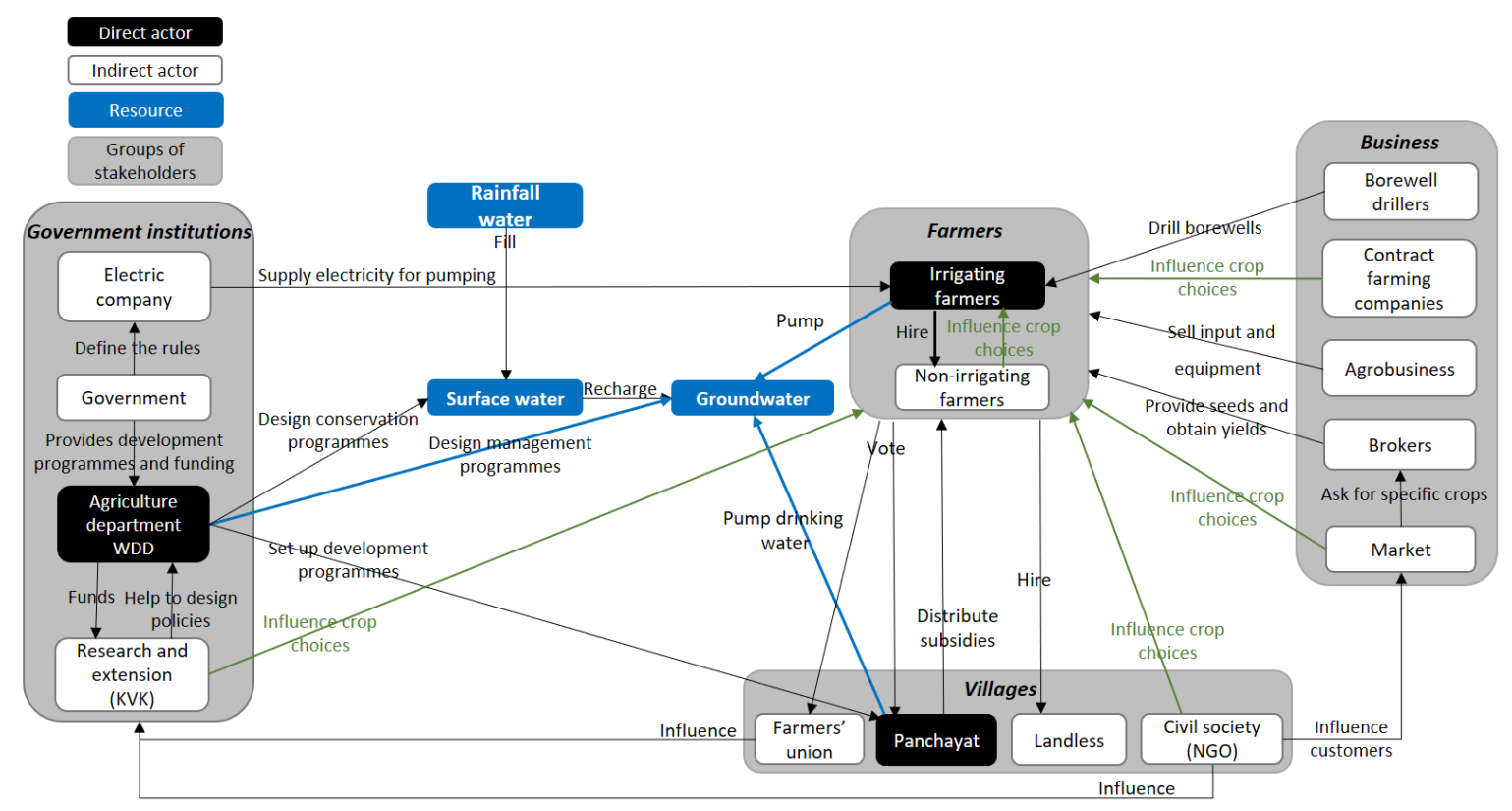

Figure 5. Mapping of stakeholders, resources and their interactions (adaptation of the "actors-resources-dynamicsinteractions" method.

\subsection{Adaptation Scenarios to Address Climate Change}

3.3.1. Potential Policies to Manage Water Resources in Response to Climate Change Effects

A wide variety of potential policies that address climate change specific to the Berambadi watershed were identified by 16 officers from the WDD and KVK, who are recognised as the main stakeholders involved in water management policies in the state of Karnataka. They proposed policies that targeted different scales (e.g., shared areas, all types of farms, irrigated farms, rainfed farms) and purposes (Table 1). Some policies aimed to build infrastructure to harvest water, such as a dam reservoir (check dam), diversion reservoir (nala 
bund), contour bunding, contour trenching or bench terracing for "individual farms and shared areas". For "shared areas", the participants also proposed landscape management, such as increasing the area of forest or pasture. For "all types of farms", they mentioned two policy purposes: (i) building infrastructure such as farm ponds (i.e., small tanks or reservoirs on farms to store rainwater from surface runoff) to harvest water and (ii) encouraging technical practices to conserve water (e.g., mulching and anti-transpirant crop techniques). For "irrigated farms", all the policies proposed focused on using less water: installing drip irrigation and smart sensors (tensiometers) to schedule irrigation, increasing access to weather information and encouraging application of recommended water doses. For "rainfed farms", the policies included promoting crops or varieties adapted to severe climatic conditions (e.g., short-cycle, dryland-adapted, late-sowing, day-neutral).

\subsubsection{Two Scenarios to Manage Water Resources in Response to Climate Change Effects}

To transform the potential policies into scenarios, a local NGO (which, in addition to helping farmers with their concerns, can influence policymakers) was included with the institutions (WDD and KVK) at this stage. It was included to add the opinion of civil society to those of the governmental institutions about implementation of the proposed policies. We focused on the two main policies for adapting to climate change that the stakeholders proposed: (i) building farm ponds and (ii) installing drip irrigation and smart sensors to schedule irrigation.

- First scenario: harvesting runoff water in farm ponds

The WDD recommended installing two types of farm ponds based on the location within the watershed: storage ponds for irrigation in the west, where groundwater levels are higher, and groundwater recharge ponds in the east, where groundwater levels are lowest (Figure 6). The storage ponds, which are lined to prevent infiltration, are used exclusively for irrigation but concern all farms, even those that are currently rainfed. Using water from storage ponds efficiently requires micro-irrigation (drip or sprinkler irrigation). In comparison, groundwater recharge ponds, which are not lined, are used exclusively to recharge groundwater and thus benefit borewells. Thus, by using the two types of ponds, it is expected that the groundwater level will stabilize once recharged and withdrawn for irrigation rebalance. Moreover, the increase in water availability (storage ponds and groundwater) will enable farmers to diversify by growing high-value-added crops, intensifying crops (more crops per year, at least in the rainy season) and developing associated activities (e.g., fodder, small ruminants, poultry). This would maintain crops and yields and increase farmers' income. In addition, development at the watershed level will create employment opportunities (e.g., agricultural work, processing, branding, marketing) and promote development of mechanised services (e.g., harvesting, sowing). However, rainfed farms with a groundwater recharge pond will be excluded from this socio-economic development. 
Table 1. Potential policies proposed by the WDD and KVK officers to address effects of climate change.

\begin{tabular}{|c|c|c|c|}
\hline Purpose of the Policy & $\begin{array}{c}\% \text { of } \\
\text { Responses }\end{array}$ & Policy & Explanation \\
\hline \multicolumn{4}{|c|}{ For individual farms or shared areas } \\
\hline $\begin{array}{l}\text { Build infrastructure to } \\
\text { harvest water }\end{array}$ & 13.5 & $\begin{array}{l}\text { Check dam, nala bund, contour } \\
\text { bunding, contour trenching or } \\
\text { bench terracing }\end{array}$ & $\begin{array}{c}\text { Increase the water resource (stored water) } \\
\text { Address extreme events } \\
\text { Mandatory at sites that require it } \\
\text { Performed by the NGO, the government and } \\
\text { farmers }\end{array}$ \\
\hline \multicolumn{4}{|c|}{ For all types of farms } \\
\hline $\begin{array}{l}\text { Build infrastructure to } \\
\text { harvest water }\end{array}$ & 18.5 & Farm ponds (runoff harvesting) & $\begin{array}{l}\text { For groundwater recharge only, for irrigation } \\
\text { only, or for both }\end{array}$ \\
\hline \multirow{2}{*}{$\begin{array}{c}\text { Encourage technical practices } \\
\text { to conserve water }\end{array}$} & 4.5 & Mulching methods & $\begin{array}{l}\text { Decrease water evaporation (using crop } \\
\text { residues available in the field) }\end{array}$ \\
\hline & 4.5 & $\begin{array}{l}\text { Anti-transpirant crop } \\
\text { techniques }\end{array}$ & Reduce crop transpiration \\
\hline \multicolumn{4}{|c|}{ For irrigated farms } \\
\hline \multirow{3}{*}{$\begin{array}{l}\text { Develop of technologies to } \\
\text { conserve water }\end{array}$} & 18.5 & $\begin{array}{l}\text { Drip irrigation (or sprinkler) } \\
\text { and smart sensors to improve } \\
\text { irrigation scheduling }\end{array}$ & $\begin{array}{c}\text { Improve irrigation efficiency } \\
\text { and } \\
\text { Provide technical information (education and } \\
\text { capacity building) } \\
\text { Create awareness through departments and } \\
\text { the NGO } \\
\text { Use smart sensors (tensiometers) }\end{array}$ \\
\hline & 4.5 & Weather information & $\begin{array}{c}\text { Development of media and apps } \\
\text { Databases to provide data to farmers, water } \\
\text { managers, etc. }\end{array}$ \\
\hline & 4.5 & $\begin{array}{l}\text { Recommended Water Dose } \\
\text { (RWD) }\end{array}$ & $\begin{array}{l}\text { RWD for flood irrigation based on research } \\
\text { Install water measuring equipment at the } \\
\text { field level }\end{array}$ \\
\hline \multicolumn{4}{|c|}{ For rainfed farms } \\
\hline \multirow{3}{*}{$\begin{array}{l}\text { Promote crops adapted to } \\
\text { severe climate conditions }\end{array}$} & 9 & Short-cycle crop varieties & $\begin{array}{l}\text { To adapt to delayed monsoon } \\
\text { Growing crops with a 70-day cycle (instead } \\
\text { of } 90 \text { - to } 100 \text {-day cycles). }\end{array}$ \\
\hline & 4.5 & Crops adapted to dryland & $\begin{array}{l}\text { Drought-tolerant crops adapted to dryland } \\
\text { (e.g., tamarind, cashew, amla, jamun, } \\
\text { mustard) }\end{array}$ \\
\hline & 4.5 & $\begin{array}{l}\text { Late-sowing and day-neutral } \\
\text { varieties }\end{array}$ & $\begin{array}{c}\text { Drought-tolerant crops and those adapted to } \\
\text { delayed monsoon } \\
\text { Provide research on all such crops }\end{array}$ \\
\hline \multicolumn{4}{|c|}{ For shared areas } \\
\hline \multirow[b]{2}{*}{ Landscape management } & 4.5 & Increase forest area & $\begin{array}{l}\text { Recharge groundwater } \\
\text { Trap evaporation }\end{array}$ \\
\hline & 9.0 & $\begin{array}{l}\text { Increase pasture area (in shared } \\
\text { areas, forest and hilly areas) }\end{array}$ & $\begin{array}{c}\text { Recharge groundwater } \\
\text { Prevent erosion and protect soil fertility (use } \\
\text { forage varieties with deep roots) } \\
\text { Provide food to animals } \\
\text { (NGO or state services in shared areas) }\end{array}$ \\
\hline
\end{tabular}




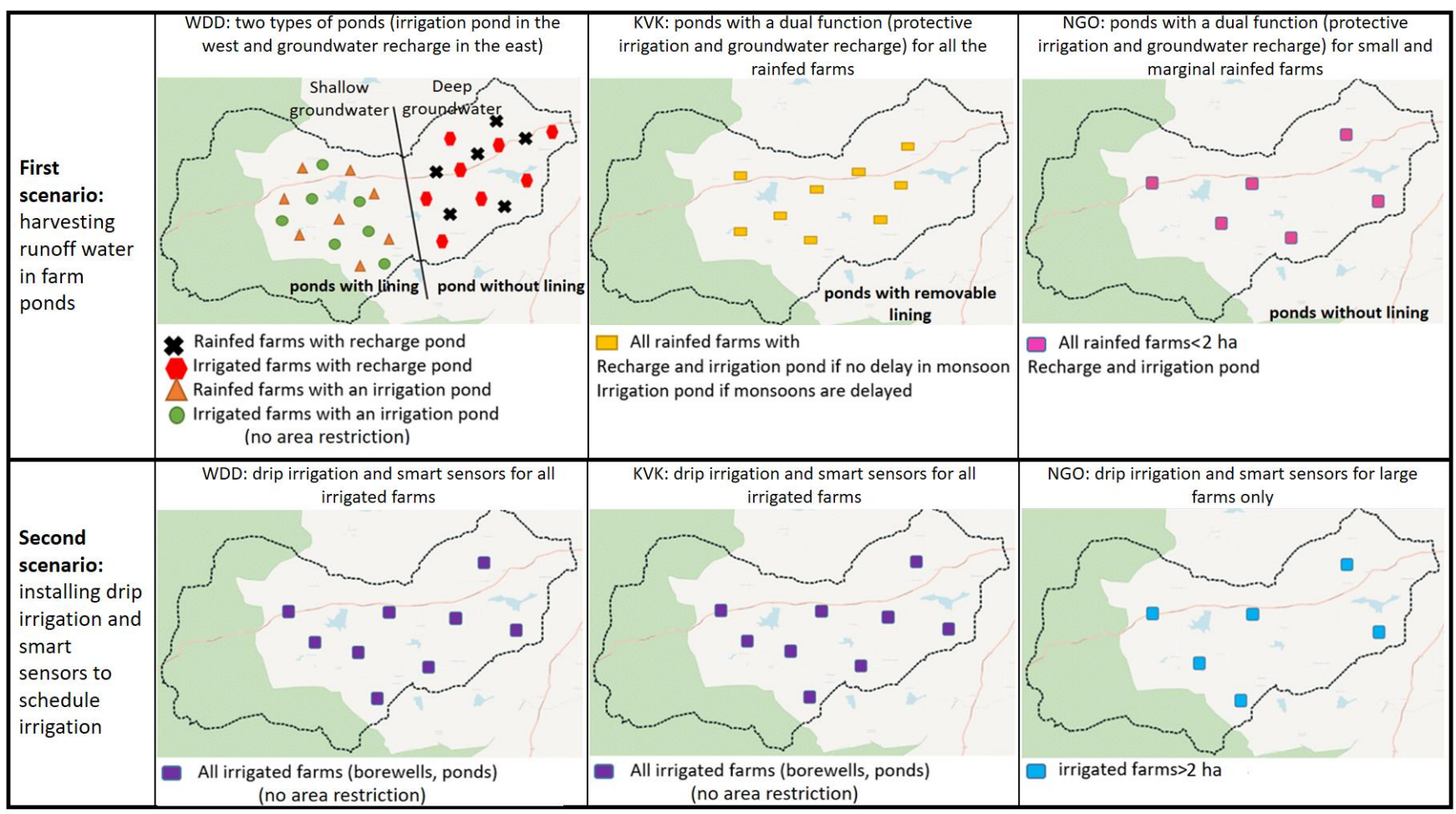

Figure 6. Diagram of implementation of the two scenarios according to the three groups of stakeholders (watershed development department (WDD), local agricultural technical and advisory centre (KVK) and non-governmental development organisation (NGO)).

The KVK focused on rainfed farms, for which they proposed installing ponds with a dual function: protective irrigation and groundwater recharge. In years with low rainfall or a delayed monsoon, the pond could be lined to keep it exclusively for irrigation. In this case, the groundwater would be recharged by other recharge structures in the area (e.g., tanks). According to the KVK, these ponds can increase the groundwater level and provide protective irrigation that ensures crop growth during dry spells and critical stages of crop development. Thus, the KVK considers that the rainfed farms will be able to keep the same production system, with integrated crops adapted to the soil and agro-climatic conditions in the region. Additionally, rainfed farms will be able to improve their land use by producing at least one double crop each year (in the rainy season) and increasing their production. Consequently, this situation is likely to reduce the vulnerability of these farms by decreasing their debts and increasing their incomes. In addition, intensification of their crops implies increasing demand for labour, which would keep the farmers, as well as daily wage workers, within the region. In return, this would decrease long-term and seasonal migration.

The NGO focused on the most vulnerable farms-small and marginal rainfed farms (i.e., $<2 \mathrm{ha}$ ) - that are numerous in the watershed and for which they proposed another type of dual-purpose pond. In addition to increasing the groundwater level, these ponds would provide protective irrigation for rainfed crops to prevent crop failure and to reduce the amount of abandoned land. Thus, in addition to diversifying and intensifying crops on these farms, by growing more crops per year (in the rainy season), the cultivated area of the watershed would increase. As a result, these ponds would help secure the income of these small farms and reduce socio-economic inequalities at the watershed level. Moreover, the increase in cultivated area would increase the demand for labour and decrease seasonal migration.

- Second scenario: installing drip irrigation and smart sensors to schedule irrigation

The WDD and KVK agreed on this scenario and targeted all irrigated farms in the watershed, regardless of their size or irrigation source (borewell and/or pond). According 
to these stakeholders, drip irrigation and smart sensors for scheduling irrigation will decrease water loss from evaporation and increase water-use efficiency at the farm level, resulting in "more crop per drop". Thus, conserving water at the farm level will stabilize the groundwater level and expand the irrigated area at the farm level (for a given volume of water, drip irrigation can irrigate ca. 2 times as much area as flood irrigation). Greater water availability at the farm level will allow for a wider variety of crops (e.g., vegetables, horticulture, orchards, fodder) with higher yields and encourage more associated activities (e.g., poultry, livestock). Thus, these farmers are likely to earn more income, especially since drip irrigation will reduce the labour costs associated with irrigation. As with dual-purpose ponds, increasing the cultivated area will increase demand for labour and thus decrease seasonal migration across the region.

The NGO believed that drip irrigation would expand the irrigated area and increase water demand, thus increasing groundwater extraction. The groundwater level would decrease considerably if this technique were installed on all irrigated farms in the watershed. Thus, the NGO targeted only large farms ( $>2$ ha) for this technology because, unlike small farms, they would decrease the risk of expanding the irrigated area, as their entire area is usually already irrigated. Thus, reducing evaporation losses for large farms through drip irrigation could conserve a large amount of water, which would then increase the groundwater level. However, this would not significantly change the production systems on these farms or the socio-economic development of the watershed area.

\section{Discussion}

\subsection{Participatory Approach}

The ABASS approach provided an overview of the groundwater problem and adaptation scenarios for groundwater management in the context of climate change. It did so by hybridizing several methods that already existed but were rarely combined.

As the stakeholders had limited availability and their interaction time was relatively short, it was necessary to prepare these meetings and target the appropriate supports to facilitate participation and interaction. For this reason, we worked with scientists from multiple fields as experts involved in research in the Berambadi watershed for many years. Their involvement helped us understand the state of groundwater depletion and identify the stakeholders involved in groundwater management, as well as the biophysical and socio-economic dynamics related to groundwater. Working with experts enabled us to prepare a range of supports and materials for reflection, such as the ZADA map and the assumption tree, to provide concrete forms of abstract information and to support mutual learning and shared information during interactions with stakeholders $[43,44]$.

Natural resource management involves complex ecological and socio-political systems that operate at multiple scales [13]. However, a growing body of literature indicates that scale framing is far from straightforward, as there is no "natural" boundary that encompasses both socio-political and ecological systems [45]. There are many reports of disappointing outcomes of participatory projects due to boundary mismatches [46,47]. For example, Levain et al. [48] described a participatory project that focused on co-building solutions to address algal blooms in a coastal watershed in Brittany, France; they showed that a shift in the socio-political boundary from local to national during the project resulted in mismatches with the ecological boundaries and thus to the disengagement of local stakeholders. Consequently, the challenge is to find a "middle path" that considers the complexity of scales and ensures participation of upper-level (e.g., national, regional) and local-level stakeholders to design efficient and applicable solutions [49]. The Berambadi watershed enabled us to meet this challenge, first because it is a concrete example of aquifer overexploitation, which helped in identifying relevant scenarios, and second, because it was not the main focus, scale or a privileged issue for any of the stakeholders involved (WDD, KVK and the NGO operate at the state, district and village scale, respectively). Thus, it highlighted stakeholders' divergent views of groundwater management among the political (WDD), technical (KVK) and civil-society (NGO) spheres. 


\subsection{Relevance of the Stakeholders' Scenarios}

The two scenarios that the stakeholders proposed to address effects of climate change were not innovative, as they corresponded to existing measures under development in state and central government schemes, such as the "Integrated Watershed Management Programme" and "Mahatma Gandhi National Rural Employment Guarantee Act" [50]. This highlights that the stakeholders' views conform to national and local programmes and schemes; however, the relevance of these scenarios is strongly debated in the scientific literature.

The scenario of "harvesting runoff water in farm ponds" was advocated by the WDD, KVK and also by several scientists, who argued that the ponds provide a range of benefits not only at the farm level (e.g., reducing risks of agricultural production, bridging the yield gap, improving cropping diversity and intensity, increasing land values and farm profitability) but also at the watershed level (e.g., increasing groundwater recharge, regulating streamflow and surface storage, reducing soil erosion) [50,51]. Nevertheless, in practice, the success and sustainability of farm ponds vary and depend greatly on the biophysical and socio-economic context of a given site [52]. While many success stories of farm pond development have been reported in several parts of India, constraints to their development and failures in their use have also been identified [50]. The two main obstacles to developing farm ponds are their high investment cost (INR 30,000-80,000), which penalises small and marginal farmers, and their occupation of arable land (2-5\% of a farm's area), which strongly impacts the livelihood of the farms [50]. Moreover, the pond use can fail because the pond was not designed well enough for effective water storage due to a lack of quantification of the biophysical and socio-economic criteria, or due to inefficient use of harvested water [52]. The water that ponds harvest in the rainy season provides protective irrigation during periods of water stress that increase the performance of rainfed crops or can help to diversify crops by allowing high-value-added crops to be produced. After the rainy season, the water harvested can provide pre-sowing irrigation, which increases cropping intensity [52]. These practices depend on the site and the dimension of the pond, and farmers do not necessarily optimise the use of harvested water [51].

The "installing drip irrigation and smart sensors to schedule irrigation" scenario also raises concerns about its ability to conserve groundwater and increase resilience to climate change. As the WDD and KVK indicated, much evidence exists that drip irrigation, in addition to increasing agricultural production in Indian semi-arid agricultural ecosystems, provides long-term sustainable economic benefits by increasing water-use efficiency $[53,54]$. However, installing drip irrigation will not conserve groundwater if it encourages farmers to increase the area under irrigation and intensify production $[55,56]$. This is the Jevons paradox (i.e., rebound effect) reported by the NGO, in which adopting a more efficient natural resource technology results in an increase rather than a decrease in the use of a natural resource [57]. Moreover, in India, where agricultural development policy encourages intensifying and expanding the area of irrigated cash crops that have high water demand, installing drip irrigation would increase water use and exacerbate the decrease in groundwater [58]. Thus, water conservation technologies alone will not conserve water without developing associated groundwater-withdrawal regulations [58].

\section{Conclusions}

The ABASS approach was developed to build adaptation scenarios of the water crisis in South India in the context of climate change. However, we believe that this method can be used in other contexts of groundwater depletion, whether in India or worldwide, and it can also be adapted to tackle other natural resource issues in the context of climate change. ABASS was developed by incorporating methods used for participatory approaches, and it involved scientific experts and stakeholders. The scientific experts helped us to assess the state of groundwater overexploitation and the effects of climate change on the hydroagricultural system and to identify the socio-political system inherent to groundwater 
management and use. The stakeholders and policymakers helped us to identify several potential adaptation policies to address the water crisis and then to transform the two main policies into scenarios. The scenarios reflected the stakeholders' opinions about how to implement the selected policies. The diversity of scenarios reflected differences in stakeholders' opinions about water resource management in the political (WDD), technical (KVK) and civil-society (NGO) spheres.

Choosing the most suitable scenario for the Berambadi context requires using a model to estimate scenario effects at the farm and watershed levels. The model must simulate the processes that underlie the scenarios built with the stakeholders and must produce results (scenario effects) in the form of indicators that are relevant to these stakeholders. This study involved mainly stakeholders who are policymakers, with the goal to explore policies for adapting to climate change. However, to ensure that farmers would accept and adopt the scenarios, it would be useful to ensure communication between these two groups.

Author Contributions: Conceptualisation, M.B., J.-E.B., S.C. and D.L.; data curation, M.B., S.C. and D.L.; formal analysis, M.B., J.-E.B., S.C. and D.L.; funding acquisition, L.R.; investigation, M.B., J.-E.B., S.C., M.S., L.R. and D.L.; methodology, M.B., J.-E.B., S.C. and D.L.; project administration, L.R.; resources, M.S. and L.R.; supervision, J.-E.B., L.R. and D.L.; validation, M.B., J.-E.B., S.C., L.R. and D.L.; visualization, M.B.; writing—original draft, M.B.; writing—review and editing, M.B., J.-E.B., L.R. and D.L. All authors have read and agreed to the published version of the manuscript.

Funding: The study was funded by the project ATCHA ANR-16-CE03-0006.

Institutional Review Board Statement: Not applicable.

Informed Consent Statement: Not applicable.

Data Availability Statement: Not applicable.

Acknowledgments: We thank the Karnataka Watershed Development Department and SUJALA III project team members for their participation and support. Our special thanks go to the extension scientists from several Krishi Vigyan Kendra (KVK) in Karnataka and to members of the NGO Punarchit who participated in the research and generously contributed their ideas and time. We also thank the Environmental Research Observatory M-TROPICS for their support.

Conflicts of Interest: The authors declare no conflict of interest. The funders had no role in the design of the study; in the collection, analyses, or interpretation of data; in the writing of the manuscript; or in the decision to publish the results.

\section{References}

1. Krishnan, R.; Sanjay, J.; Gnanaseelan, C.; Mujumdar, M.; Kulkarni, A.; Chakraborty, S. Assessment of Climate Change over the Indian Region: A Report of the Ministry of Earth Sciences (MOES), Government of India; Springer Nature: Singapore, 2020; p. 226.

2. Wang, X.J.; Zhang, J.Y.; Shahid, S.; Guan, E.H.; Wu, Y.X.; Gao, J.; He, R.M. Adaptation to climate change impacts on water demand. Mitig. Adapt. Strat. Glob. Chang. 2016, 21, 81-99. [CrossRef]

3. March, H.; Therond, O.; Leenhardt, D. Water futures: Reviewing water-scenario analyses through an original interpretative framework. Ecol. Econ. 2012, 82, 126-137. [CrossRef]

4. Iglesias, A.; Garrote, L. Adaptation strategies for agricultural water management under climate change in Europe. Agric. Water Manag. 2015, 155, 113-124. [CrossRef]

5. Megdal, S.B.; Eden, S.; Shamir, E. Water Governance, Stakeholder Engagement, and Sustainable Water Resources Management. Water 2017, 9, 190. [CrossRef]

6. Koontz, T.M.; Thomas, C.W. What Do We Know and Need to Know about the Environmental Outcomes of Collaborative Management? Public Adm. Rev. 2006, 66, 111-121. [CrossRef]

7. Murgue, C.; Therond, O.; Leenhardt, D. Toward integrated water and agricultural land management: Participatory design of agricultural landscapes. Land Use Policy 2015, 45, 52-63. [CrossRef]

8. Barreteau, O.; Bots, P.W.G.; Daniell, K.A. A Framework for Clarifying "Participation" in Participatory Research to Prevent its Rejection for the Wrong Reasons. Ecol. Soc. 2010, 15, 1. [CrossRef]

9. Garrod, G.; Raley, M.; Aznar, O.; Espinosa, O.B.; Barreteau, O.; Gómez, M.; Schaft, F.; Turpin, N. Engaging stakeholders through participatory modelling. Proc. Inst. Civ. Eng. Eng. Sustain. 2013, 166, 75-84. [CrossRef] 
10. Butler, C.; Adamowski, J. Empowering marginalized communities in water resources management: Addressing inequitable practices in Participatory Model Building. J. Environ. Manag. 2015, 153, 153-162. [CrossRef] [PubMed]

11. Wilcox, D. The Guide to Effective Participation; Delta Press: Brighton, UK, 1994; p. 64.

12. Rowe, G.; Marsh, R.; Frewer, L.J. Evaluation of a deliberative conference in science. Technol. Hum. Values 2004, $29,88-121$. [CrossRef]

13. Reed, M.S. Stakeholder participation for environmental management: A literature review. Biol. Conserv. 2008, 141, $2417-2431$. [CrossRef]

14. Lacroix, K.E.M.; Megdal, S.B. Explore, Synthesize, and Repeat: Unraveling Complex Water Management Issues through the Stakeholder Engagement Wheel. Water 2016, 8, 118. [CrossRef]

15. Orlando, F.; Alali, S.; Vaglia, V.; Pagliarino, E.; Bacenetti, J.; Bocchi, S. Participatory approach for developing knowledge on organic rice farming: Management strategies and productive performance. Agric. Syst. 2020, 178, 102739. [CrossRef]

16. Yen, B.T.; Son, N.H.; Tung, L.T.; Amjath-Babu, T.; Sebastian, L. Development of a participatory approach for mapping climate risks and adaptive interventions (CS-MAP) in Vietnam's Mekong River Delta. Clim. Risk Manag. 2019, 24, 59-70. [CrossRef]

17. Micha, E.; Roberts, W.; Ryan, M.; O’Donoghue, C.; Daly, K. A participatory approach for comparing stakeholders' evaluation of P loss mitigation options in a high ecological status river catchment. Environ. Sci. Policy 2018, 84, 41-51. [CrossRef]

18. Verkerk, P.J.; Sánchez, A.; Libbrecht, S.; Broekman, A.; Bruggeman, A.; Daly-Hassen, H.; Giannakis, E.; Jebari, S.; Kok, K.; Klemenčič, A.K.; et al. A Participatory Approach for Adapting River Basins to Climate Change. Water 2017, 9, 958. [CrossRef]

19. Antwi-Agyei, P.; Quinn, C.H.; Adiku, S.G.K.; Codjoe, S.N.A.; Dougill, A.J.; Lamboll, R.; Dovie, D.B.K. Perceived stressors of climate vulnerability across scales in the Savannah zone of Ghana: A participatory approach. Reg. Environ. Chang. 2016, 17, 213-227. [CrossRef]

20. Lunt, T.; Ellis-Jones, J.; Mekonnen, K.; Schulz, S.; Thorne, P.; Schulte-Geldermann, E.; Sharma, K. Participatory community analysis: Identifying and addressing challenges to Ethiopian smallholder livelihoods. Dev. Pract. 2018, 28, 208-226. [CrossRef]

21. Shah, S.H.; Narain, V. Re-framing India's "water crisis": An institutions and entitlements perspective. Geoforum 2019, 101, 76-79. [CrossRef]

22. Alcamo, J. Scenarios as Tools for International Assessments; Environmental Issue Report 24; European Environmental Agency: Copenhagen, Denmark, 2001; p. 31.

23. Alcamo, J. Environmental Futures: The Practice of Environmental Scenarios; Elsevier: Amsterdam, The Netherlands, 2008 ; p. 212.

24. Andersen, E.; Elbersen, B.; Godeschalk, F.; Verhoog, D. Farm management indicators and farm typologies as a basis for assessments in a changing policy environment. J. Environ. Manag. 2007, 82, 353-362. [CrossRef] [PubMed]

25. Sekhar, M.; Riotte, J.; Ruiz, L.; Jouquet, J.; Braun, J.J. Influences of Climate and Agriculture on Water and Biogeochemical Cycles: Kabini Critical Zone Observatory. Proc. Indian Natl. Sci. Acad. 2016, 82, 82. [CrossRef]

26. Buvaneshwari, S.; Riotte, J.; Sekhar, M.; Kumar, M.M.; Sharma, A.K.; Duprey, J.L.; Audry, S.; Giriraja, P.; Praveenkumarreddy, Y.; Moger, H.; et al. Groundwater resource vulnerability and spatial variability of nitrate contamination: Insights from high density tubewell monitoring in a hard rock aquifer. Sci. Total Environ. 2017, 579, 838-847. [CrossRef]

27. Buvaneshwari, S.; Riotte, J.; Sekhar, M.; Sharma, A.K.; Helliwell, R.; Kumar, M.S.M.; Braun, J.J.; Ruiz, L. Potash fertilizer promotes incipient salinization in groundwater irrigated semi-arid agriculture. Sci. Rep. 2020, 10, 3691. [CrossRef] [PubMed]

28. Robert, M.; Thomas, A.; Sekhar, M.; Badiger, S.; Ruiz, L.; Willaume, M.; Leenhardt, D.; Bergez, J.-E. Farm Typology in the Berambadi Watershed (India): Farming Systems Are Determined by Farm Size and Access to Groundwater. Water $2017,9,51$. [CrossRef]

29. Ruiz, L.; Sekhar, M.; Thomas, A.; Badiger, S.; Bergez, J.E.; Buis, S.; Gascuel, C. Adaptation of irrigated agriculture to climate change: Trans-disciplinary modelling of a watershed in South India. In Proceedings of the 11th Kovacs Colloquium on Hydrological Sciences and Water Security: Past, Present and Future, Paris, France, 16-17 June 2014.

30. Jogesh, A.; Dubash, N.K. Mainstreaming Climate Change in State Development Planning: An analysis of Karnataka's Action Plan on Climate Change; Centre for Policy Research, Climate Initiative: New Delhi, India, 2014; p. 14.

31. Halbe, J.; Adamowski, J. Use of participatory system dynamics modelling for collaborative watershed management in Quebec, Canada. J. Agric. Eng. 2011, 48, 21-29.

32. Caron, P.; Cheylan, J.-P. Donner sens à l'information géographique pour accompagner les projets de territoire: Cartes et représentations spatiales comme supports d'itinéraires croisés. Géocarrefour 2005, 80, 111-122. [CrossRef]

33. Saqalli, M.; Caron, P.; Defourny, P.; Issaka, A. The PBRM (perception-based regional mapping): A spatial method to support regional development initiatives. Appl. Geogr. 2009, 29, 358-370. [CrossRef]

34. Caron, P. Le zonage à dires d'acteurs pour comprendre et décider. Le municipe au Brésil. In Représentations Spatiales et dé-Veloppement Territorial; Lardon, S., Maurel, P., Piveteau, V., Eds.; Hermès-Lavoisier: Cachan, France, 2001 ; pp. $343-357$.

35. Hare, M.; Pahl-Wostl, C. Stakeholder categorization in participatory integrated assessment processes. Integr. Assess. 2002, 3, 50-62. [CrossRef]

36. Etienne, M.; Du Toit, D.R.; Pollard, S. ARDI: A Co-construction Method for Participatory Modeling in Natural Resources Management. Ecol. Soc. 2011, 16, 44. [CrossRef]

37. Anselme, B.; Bousquet, F.; Lyet, A.; Etienne, M.; Fady, B.; Le Page, C. Modelling of spatial dynamics and biodiversity conservation on Lure mountain (France). Environ. Model. Softw. 2010, 25, 1385-1398. [CrossRef] 
38. Simon, C.; Etienne, M. A companion modelling approach applied to forest management planning. Environ. Model. Softw. 2010, 25, 1371-1384. [CrossRef]

39. Patel, M.; Kok, K.; Rothman, D.S. Participatory scenario construction in land use analysis: An insight into the experiences created by stakeholder involvement in the Northern Mediterranean. Land Use Policy 2007, 24, 546-561. [CrossRef]

40. Leenhardt, D.; Therond, O.; Cordier, M.-O.; Gascuel-Odoux, C.; Reynaud, A.; Durand, P.; Bergez, J.-E.; Clavel, L.; Masson, V.; Moreau, P. A generic framework for scenario exercises using models applied to water-resource management. Environ. Model. Softw. 2012, 37, 125-133. [CrossRef]

41. Vinck, D. Les objets intermédiaires dans les réseaux de coopération scientifique: Contribution à la prise en compte des objets dans les dynamiques sociales. Rev. Française Sociol. 1999, 40, 385. [CrossRef]

42. Rizzo, D.; Therond, O.; Lardy, R.; Murgue, C.; Leenhardt, D. A rapid, spatially explicit approach to describe cropping systems dynamics at the regional scale. Agric. Syst. 2019, 173, 491-503. [CrossRef]

43. Hoverman, S.; Ayre, M. Methods and approaches to support Indigenous water planning: An example from the Tiwi Islands, Northern Territory, Australia. J. Hydrol. 2012, 474, 47-56. [CrossRef]

44. Basupi, L.V.; Quinn, C.H.; Dougill, A.J. Using participatory mapping and a participatory geographic information system in pastoral land use investigation: Impacts of rangeland policy in Botswana. Land Use Policy 2017, 64, 363-373. [CrossRef]

45. Warner, J.F.; Wester, P.; Hoogesteger, J. Struggling with scales: Revisiting the boundaries of river basin management. Wiley Interdiscip. Rev. Water 2014, 1, 469-481. [CrossRef]

46. Buizer, M.; Arts, B.; Kok, K. Governance, Scale and the Environment: The Importance of Recognizing Knowledge Claims in Transdisciplinary Arenas. Ecol. Soc. 2011, 16, 105751. [CrossRef]

47. Van Lieshout, M.; Dewulf, A.; Aarts, N.; Termeer, C. Do Scale Frames Matter? Scale Frame Mismatches in the Decision Making Process of a "Mega Farm" in a Small Dutch Village. Ecol. Soc. 2011, 16, 38. [CrossRef]

48. Levain, A.; Vertes, F.; Ruiz, L.; Delaby, L.; Gascuel-Odoux, C.; Barbier, M. 'I am an Intensive Guy': The Possibility and Conditions of Reconciliation Through the Ecological Intensification Framework. Environ. Manag. 2015, 56, 1184-1198. [CrossRef]

49. Cash, D.W.; Adger, W.N.; Berkes, F.; Garden, P.; Lebel, L.; Olsson, P.; Pritchard, L.; Young, O. Scale and Cross-Scale Dynamics: Governance and Information in a Multilevel World. Ecol. Soc. 2006, 11, 8. [CrossRef]

50. Rao, C.S.; Rejani, R.; Rao, C.A.R.; Rao, K.V.; Osman, M.; Reddy, K.S.; Kumar, M.; Kumar, P. Farm Ponds for Climate-Resilient Rainfed Agriculture. Curr. Sci. 2017, 112, 471. [CrossRef]

51. Jain, V.; Rathore, A.; Bisen, A.; Rajak, K. Smart Rainwater Storage Technologies for Increasing Farmer's Economy in Rainfed and Tribal areas of Chhattisgarh. Int. J. Curr. Microbiol. Appl. Sci. 2019, 8, 2083-2090. [CrossRef]

52. Vote, C.; Eberbach, P.; Inthavong, T.; Lampayan, R.M.; Vongthilard, S.; Wade, L.J. Quantification of an overlooked water resource in the tropical rainfed lowlands using RapidEye satellite data: A case of farm ponds and the potential gross value for smallholder production in southern Laos. Agric. Water Manag. 2019, 212, 111-118. [CrossRef]

53. Surendran, U.; Jayakumar, M.; Marimuthu, S. Low cost drip irrigation: Impact on sugarcane yield, water and energy saving in semiarid tropical agro ecosystem in India. Sci. Total Environ. 2016, 573, 1430-1440. [CrossRef] [PubMed]

54. Narayanamoorthy, A.; Bhattarai, M.; Jothi, P. An assessment of the economic impact of drip irrigation in vegetable production in India. Agric. Econ. Res. Rev. 2018, 31, 105. [CrossRef]

55. van der Kooij, S.; Zwarteveen, M.; Boesveld, H.; Kuper, M. The efficiency of drip irrigation unpacked. Agric. Water Manag. 2013, 123, 103-110. [CrossRef]

56. Fishman, R.; Devineni, N.; Raman, S. Can improved agricultural water use efficiency save India's groundwater? Environ. Res. Lett. 2015, 10, 084022. [CrossRef]

57. Dumont, A.; Mayor, B.; López-Gunn, E. Is the Rebound Effect or Jevons Paradox a Useful Concept for better Management of Water Resources? Insights from the Irrigation Modernisation Process in Spain. Aquat. Procedia 2013, 1, 64-76. [CrossRef]

58. Birkenholtz, T. Assessing India's drip-irrigation boom: Efficiency, climate change and groundwater policy. Water Int. 2017, 42, 663-677. [CrossRef] 